land-based agriculture. By all accounts, tho material grows plants well although it may be somewhat deficient in potassium. Nothing is known as yet of the likely reaction of lake biologists to the suggestion that the lake sediments may be exploited in ways like this.

More active ways of regulating the conditions of eutrophic lakes have also been described in the past few days. N. R. Sedlander of the University of Toledo has been exploring the use of low pressure aeration as a way of treating water in shallow ponds alongside some of the Great Lakes. 'Two engineers of Gurnham and Associates Inc. of Chicago advocated this week the use of low pressure aeration as a way of building in situ treatment plants within bodies of eutrophic water. The construction of good mathematical models for polluted lakes is also now recognized to bc one valuable way of predicting what the consequences of alternative treatments may be.

Industrial enterprises recently pilloried for their part in the pollution of the Great Lakes have stoutly defended themselves in the past few days from some of their critics. Mr A. S. Merrow from the Lackawanna plant of the Bethlehem Steel Corporation described the steps being taken by his company to reduce its contribution of pollutants to Lake Erie. The most spectacular feature of this programme is a sunken well for the disposal of acidic liquors which the company has been allowed to sink but not yet to put into service. Mr P. J. Wallace of the Consumers' Gas Company, Toronto, the chief explorer for natural gas in Lake Erie, held that this activity is less of a hazard to the environment than conservationists had claimed. Would-be builders of nuclear power stations on the Great Lakes described studies being carried out to ensure that no damage is done by the discharge of water and, in the process, sometimos conveyed the impression that in present circumstances no proposal for a new power station could succeed without a substantial kickback in the form of a research contract to the biology department of the local university. The most depressing part of this symposium was the account by $\mathrm{Mr}$ A. Pagnano of the New York State Health Department of the slow progress in deciding how to set up permanent control measures for the effluents produced by the 2,500 industrial enterprises which are potential sources of pollution in New York State.

Against this background, the most heartening of the proceedings this week has been the descriptions of new proposals for Great Lakes research. Both the United States and Canada, with the latter forcing the pace, are planning what they call the International Field Year for the Great Lakes-a plan to colloct data about Lake Ontario during 1972 as part of the contribution of both countries to the International Hydrological Decade. One part of the programme is based on the view that Lake Ontario is a splendid model ocean for studying the intercation between atmospheric processes and the water surface. The thermal structure of the lake will be studied intensively and an attempt will be made to construct an accurate balance of the flux of water in and out of the lake, particularly by means of underground aquifers. There is also to be a careful study of the movement of water within the lake. Together with studies such as that of Lake Erie carried out in the past few years, this work is likely to contribute in important ways to the better understanding of the lower Great Lakes.

\section{Evangelism and Pollution}

THE most fervent views on pollution and the Great Lakes were provided not by the scientists attending the conference but by $\mathrm{Mr}$ Carl L. Klein, Assistant Secretary for Water Quality and Research at the US Department of the Interior, who spoke at the conference dinner, and by a group of students representing Ecology Action who picketed the entrance. Mr Klein is known as "Clean Water Klein" because of his success in regulating water quality in the State of Illinois. His message, now reflected from a larger sounding board, is that "it is late but not too late". Mr Klein explained how the federal government is now hoping to acquire the power to enforce regulations on water quality even when issues seem to lie entirely within the jurisdiction of individual states, by asking for powers to regulate pollution on "all interstate and navigable waters and all tributaries thereto". $\mathrm{He}$ is also hoping that legislation now in Congress will accelerate the process of dealing with complaints_- "it is too late to have to wait eighteen months before wc can go to court".

Mr Klein's threats of tougher action were welcomed at the conference. Mr Klein did, however, mystify his audience by a self-congratulatory reference to the discovery by the Aerojet-General Corporation that soil acids, presumably humic acids, can break down DID'" "in a few hours". Mr Klein went on to suggest that this chemical reaction could become the basis for a new way of using DDT without having it accumulate in the soil, but questioning from the audience failed to reveal just how this would be accomplished. There was also some scepticism among former colleagues of Mr Klcin about his confident declaration that "we can clean up Lake Michigan by the middle of 1972".

$\mathrm{Mr}$ Klcin's account of pollution in the Great Lakes was lent point by the discovery that some fish in Lake Erie contained such large amounts of mercury that the Canadian Government has decided to ban their sale pending further investigation. Part of the difficulty of knowing how serious the problem may be is that there is not yet available a detailed analysis of the fish-are the high concentrations of mercury reported confined to the liver or spread through the rest of the fish? Another puzzle is the source of mercury reaching Lake Erie-Mr Klein considers that both the United States and Canada are contributing to it, but he promised vigorous action to identify the offenders. In the same spirit, he explained how the releasc of oil during the exploration of the Santa Barbara Channel last year was the result of "bad drilling regulations" and that "we replaced them with stronger regulations".

Mr Klein's confidence that things will come right-"let's make this a good earth to live on again" is what he says-is cheering. One difficulty, which his experience has equipped him to overcome, is that of enforcement. Another is that the problem of the Great Lakes may actually be more subtle than it secms to be. 